\title{
Model of Public Policy Implementation for Refused Derived Fuel (RDF) Waste Management in Cilacap Regency
}

\author{
Syamsul Auliya Rachman ${ }^{1}$, Muchlis Hamdi ${ }^{2}$, Aries Djaenuri ${ }^{3}$, Ika Sartika ${ }^{4}$ \\ 1,2,3,4 Institut Pemerintahan Dalam Negeri (IPDN), Indonesia \\ Email: ar.syamsul@gmail.com
}

\begin{abstract}
The problem of waste management in big cities worldwide and especially Indonesia, has become an ongoing issue. Every country globally competes in developing various technologies in waste management, such as sanitary landfills, incineration, gasification, and anaerobic digestion technology. This study intends to describe the right model for waste management, especially for areas in Indonesia. In this case, the writer tries to discuss waste management innovation in Cilacap Regency by using a waste management policy implementation model with Refused Derived Fuel (RDF) technology, which converts waste into alternative fuel to replace coal. In this paper, the writer tries to analyze it with a descriptive design with a qualitative approach. Writing informants were determined by purposive sampling. The results of this study, according to the author, indicate that the implementation of RDF public policy on waste management can be carried out with several approaches, namely: (1) RDF Waste Management Policy Model with a Collaborative Waste Management Service approach; (2) RDF Waste Management Policy Model with the Buy and Sell Cooperation approach of RDF results; (3) RDF Waste Management Policy Model with a Joint Venture (JO) approach; (4) RDF waste management policy model with an Operational Cooperation approach with the presence of foreign assistance, the central government and provincial governments; (5) RDF waste management policy model with the formation of regional companies.
\end{abstract}

Keywords: Policy Implementation, Public Policy, Waste Management, RDF Method.

\section{A. INTRODUCTION}

Waste is a part of something that is not used, disliked, or something that must be disposed of, which generally comes from activities carried out by humans (including industrial activities), but not biological (because human waste is not included in it) and is usually solid. (Azwar, 1990). Sources of trash can be various, including households, markets, shops, offices, public buildings, industries, and roads. Garbage is the remains of daily human activities and/or natural processes in the form of solid (Suyoto, 2008). The rate of waste production continues to increase, not only in line with the quality of population growth but also in line with society's increasing consumption patterns (Damanhuri, 2010). On the other hand, the waste handling capacity carried out by the community and local government is not optimal. Waste that is not managed correctly will affect the environment and the surrounding community's health (Demirbas, 2011).

Today, waste is one of the severe problems in the world and is very closely related to everyday human life. Everyone cannot be separated from the problem of waste, as the party produces waste (Misra \& Pandey, 2005). So it can be said that the issue of waste is a problem of public perception of waste. To achieve conditions for 
people who live healthy and prosperous in the future, it is necessary to have a healthy residential environment (Yadav et al., 2017). From solid waste, the word beneficial will mean a condition that can be achieved if the trash can be appropriately managed. It is clean from the residential environment where humans are active in it. To achieve a healthy and prosperous community condition in the future, it is necessary to have a healthy residential environment (Gray, 1997). From the aspect of solid waste, the word beneficial will mean a condition that can be achieved if the trash can be appropriately managed so that it is clean from the residential environment where humans are active in it (Sulistyorini et al., 2015)

The majority of Indonesia's waste disposal patterns are collected at a waste collection site called a landfill (TPA) (Yogiesti et al., 2012). The impact of quality degradation on the environment will occur if waste management at the TPA is not managed correctly (Nahrudin, 2016). In general, open dumping is the leading cause of damage to the environment around the landfill, such as air and water pollution, unpleasant odors, the emergence of germs, etc. (Damanhuri, 2010).

In managing waste, what has been done in urban areas is burning in open spaces in TPA (Damanhuri, 2006). This method is considered ineffective in reducing waste. It will only cause other problems, namely the formation of hazardous chemical substances, which are pollutants such as carbon dioxide, nitrate, nitrite compounds, and toxic sulfide gases (Courtemanche \& Levendis, 1998). Developed countries have developed various waste management technologies, such as sanitary landfills, incineration, gasification, and anaerobic digestion (Marshall \& Farahbakhsh, 2013). Waste handling that still relies on the concept of "collecttransport-dispose of waste" adds to the burden of waste management (Sahil et al., 2016). Limited funding in the solid waste sector has made the provision of related infrastructure significantly lagging behind the increasing volume of waste that local governments have to handle every day (Mulyadi et al., 2010). One source of financing that can be done is collecting fees for cleaning / solid waste imposed on the community. Public awareness of participating in waste management means that the amount of retribution obtained usually does not cover the operational costs of waste management (Sejati, 2009).

Discussing the problem of waste in Cilacap Regency waste management is a topic that is always discussed in the Regional Work Organization Forum for Regional Work every year. The problem is the lack of supporting equipment, facilities, and human resources involved in waste management in the Cilacap district so that the Cilacap Regency Government has not been able to provide optimal waste transportation services to the community. Based on data from the Cilacap district government in the Environmental Service, that the volume of waste produced in the Cilacap district is 400 tons per day, which is divided into four landfills which are collected every day with 34 units of garbage trucks, some of which are not suitable for use (Cilacap, 2016).

Seeing the problem of waste management, which has not been effectively resolved until now, the Regional Government of the Cilacap Regency strives to find 
the right management policy to solve the waste problem. Therefore, in 2014 the Cilacap Regency Government formed a partnership with a private company, namely PT. Solusi Bangun Indonesia (SBI), which was formerly Semen Holcim Indonesia to study the waste management system using RDF (Refused Derived Fuel) technology at TPA Tritih Lor, Jeruklegi District. The RDF waste processing system is considered an appropriate waste processing method for urban areas (Dong \& Lee, 2009; Kara, 2012). RDF technology is to turn urban waste into charcoal by pyrolysis, and after that, it is compacted so that it becomes char briquettes (Genon \& Brizio, 2008). Based on the results of writing about RDF's product output, it has a calorific value that can be used as an alternative fuel to replace coal (Himawanto et al., 2010).

Based on the various problem descriptions above, the Cilacap Regency Government hopes that RDF is an appropriate public policy to address waste management problems. The waste management policy model is a system with an open dumping system, sanitary landfill, and the $3 \mathrm{R}$ concept (Reuse, Reduce). , Recycle) has not effectively dealt with the waste problem in Cilacap Regency. Implementing waste management policies using RDF technology still leaves issues and requires a comprehensive study of these policies. Later, the policies implemented by the Cilacap Regency Government will not cause a more significant problem impact on their implementation.

\section{B. METHOD}

In this study, the research design used by the author is qualitative. Where it is said that qualitative research is a particular tradition in social science that fundamentally depends on observing humans in their area and relating to these people in their language and terms (Moleong, 2012). Descriptive research aims to create descriptions, descriptions, or paintings specific, systematic, actual, and accurate regarding facts, characteristics, social, environmental situations, and the relationships between the phenomena under study (Creswell, 2010).

Based on these characteristics, this study uses a qualitative approach by being carried out in natural conditions, is more descriptive, emphasizes the process rather than the product or outcome, performs data analysis inductively, and emphasizes meaning (reversed data is observed). Qualitative research will explain how to formulating public-private cooperation policies in waste management projects in Cilacap Regency by describing and analyzing existing data (Sugiyono, 2010).

\section{RESULT AND DISCUSSION}

The study results from the Ministry of Industry's open opportunities for cooperation between the government and state, regional or private enterprises in waste management. Opportunities for cooperation opportunities with these business entities are contained in Presidential Regulation Number 56 of 2011 and Presidential Regulation Number 13 of 2010 (amendments to Perpres No 67/2005 concerning Government Cooperation with Business Entities in Providing Infrastructure) with all the requirements. This cooperation model is often called a public-private partnership 
(PPP). The pilot project for waste management using RDF technology in Cilacap Regency, according to the author, is somewhat different from the previous PPP model. First, apart from involving state-owned companies, this pilot project also consists of the government of other countries, namely Denmark, through the Danida ESP3 Program. Second, the initiative came from the Danish government. Third, the initial investment costs of this pilot project are enormous. Fourth, the pilot project for managing waste into energy using RDF technology, which is used by the cement industry as a substitute for coal, is the first in Indonesia.

The hope of the central government is that the PPP model in RDF waste management like this can be replicated in other parts of Indonesia, which have the same relative characteristics. The biggest challenge to replicating such a cooperative model lies in the high cost. It is not yet calculated whether the benefits for the business entity are worth the costs. Technical requirements such as the amount of waste produced, the existence of a cement company or coal-fired power plant that is willing to take advantage of the RDF results, and the massive investment costs will make it difficult for other local governments to implement this innovation in RDF waste management. The RDF pilot project in Cilacap Regency requires an investment cost of approximately Rp 80 billion. The Cilacap district government will not be able to bear half of the initial costs. The private sector will not necessarily be willing to invest the other half at the start if the two cooperating parties provide mutual investment. The Cilacap Regency Government is indeed lucky because there is a grant from the Kingdom of Denmark through DANIDA ESP3, amounting to the US \$ 2.5 million.

Learning from the RDF waste management policy process in Cilacap Regency that the final goal in this paper is the realization of a cooperation model trying to offer a cooperation model that can be replicated by other regions as follows:

\section{Model of RDF Waste Management Policy with a collaborative approach to Waste Management Services}

The government is carrying out its role as a public organization always strives to provide good goods and services for its citizens, especially in public sector services or large audiences. One of them is government services in the public solid waste sector, which is the responsibility of the government for its citizens because waste management is not only seen as public goods because it involves many people but also the government is also trying to make waste have economic interests and even alternative fuels in the energy sector. Therefore, the government is interested in encouraging the Ministry of Environment and local governments so that waste can be obtained with environmentally friendly technology and is also expected to be a renewable alternative energy fuel.

Limited funds are owned, causing the government to be unable to finance all infrastructure needed by the community in public sectors such as roads, bridges, drinking water networks, ports, and waste management. Local governments also share this. The basic rules are also clear, namely Presidential Decree 38 of 2015. 
According to this Presidential Regulation, cooperation is carried out based on the principles of Partnership, Benefit, Competitive, Control and risk management, Effective, and Efficient. The infrastructure that can be cooperated based on Presidential Regulation Number 38 of 2015 is economic infrastructure and social infrastructure. Economic infrastructure and social infrastructure, one of which includes a solid waste management system infrastructure. So it is clear that waste management can cooperate with business entities or private parties. The limited budget conditions owned by local governments are also following the meaning of the making of regulations regarding cooperation with private enterprises.

The experience in Cilacap Regency when the concept of a solid waste management service cooperation policy model was rolled out was that PT. SBI refused the cooperation in RDF waste processing with a total investment value of \pm 80 billion projects because of PT. SBI also considers that the investment value is too large to be carried out. As a rule, this waste management service cooperation model can be done if the business entity has the financial capacity to build RDF infrastructure. The local government only needs to prepare a waste transportation budget and a tipping fee for private business entities.

\section{The RDF Waste Management Policy Model with the Buy and Sell Cooperation approach of the RDF results}

The waste management policy model with the buying and selling approach of RDF waste management results with business entities is when the local government has the budgetary capacity to invest as a whole in the development of RDF waste management projects, and the role of business entities is only as buyers of processed RDF products.

Business entities or local governments can be the initiators in a waste management cooperation plan with RDF technology by offering a cooperation offer letter. In the concept of cooperation above, the obligation of the local government is that it is the party to provide all of the complete RDF infrastructures. RDF's operational management is also the responsibility of the local government, and business entities contribute to buying the results of RDF waste management based on a price and timeframe that has been determined following the cooperation agreement.

This model's weakness is that local governments need to spend enormous investment costs to build RDF facilities and operations. Cooperating business entities can be direct beneficiaries or only business entities that carry out the RDF buying and selling business. If the business entity is not a direct beneficiary of RDF, then the business entity must collaborate with the company utilizing RDF.

\section{The RDF Waste Management Policy Model with a Joint Venture (JO) Collaborative Approach}

The policy model Cooperation in waste management with a joint venture (JO) approach is a collaboration between local governments and legal entities where 
responsibility and ownership are shared in terms of providing infrastructure services. In this cooperation, each party has a balanced position in collaboration. This collaboration aims to combine the advantages of the private sector, such as capital, technology, and management capabilities, with the government's benefits, namely the authority and trust of the community. In the joint venture concept, the government and the private sector can form new companies such as BUMN / BUMD or BLUD, and the companies that are established have a function that is independent of the government. Joint venture cooperation is an alternative that can be said to be a form of public-private partnership, namely between the government, private sector, non-governmental institutions, and other institutions that can contribute their resources that can "share" or share in solving local infrastructure problems.

In a joint venture collaboration, local governments and business entities must work together from the initial stage, forming institutions to project development. Financing structure in this joint venture (JO) model, the government and the private sector must contribute to financing from the start, from financing project feasibility studies to preparing investment in new companies when they are formed. The concept of shared capital in this PPP requires prior agreement to bear the risks and share the profits. In other words, each of them must have a contribution through the development project and its implementation. The emergence of the concept of joint venture cooperation between local governments and business entities that are prospective partners is usually due to the limited investment funds owned by the business entity, thus offering capital sharing to establish the RDF project.

Learning from the implementation of RDF's waste management policy in Cilacap Regency, that this joint venture cooperation model cannot be implemented due to budget constraints from the Cilacap Regency Government, which is considered to be still financing a budget to invest \pm 35 billion and is also related to land acquisition regulations for the public interest, back again, the Cilacap Regency Government must acquire the land. Other regions can implement the concept of the joint venture model that the writer offers above. It can find common ground between local government and business entities, having the budget capacity to invest in RDF waste management projects.

\section{RDF Waste Management Policy Model with an Operational Cooperation Approach with the Presence of Foreign Assistance, the Central Government and the Provincial Government}

The implementation of the RDF waste management policy implemented in the Cilacap Regency, which has problems with the limited capital owned by the Cilacap Regency Government, ultimately encourages various parties' involvement. At the beginning of the discussion, the first party to enter was DANIDA ESP3, an environmental awareness program from the Kingdom of Denmark, which, after the Cilacap Regency Government, was brought together by PT. Solusi Bangun Indonesia Tbk. as a partner of cooperation with them, DANIDA ESP3 finally agreed to provide 
RDF equipment assistance worth \pm 35 billion to the Cilacap Regency Government grant to the Ministry of Environment and Forestry.

It is almost the same as the RDF management policy model with the Operational cooperation approach because all assistance provided from foreign countries, the central government, and provincial governments granted to local governments is regional property. Grant assistance received by local governments (for example, civil work, RDF equipment, heavy equipment, and other supporting advice) is included as investment capital issued by the local government. The local government bears investment in the land prepared for the RDF project, and all operational costs are held jointly by business entities and local governments.

RDF proceeds sharing based on the results of agreements with business entities that are prospective partners and local governments. Cooperating business entities can be direct beneficiaries or only business entities that carry out the RDF buying and selling business. If the business entity is not a direct beneficiary of RDF, it must still collaborate with the company that uses RDF (for example, a cement factory).

\section{Model RDF Waste Management Policy with the Establishment of Regional Companies}

Each region has economic potential that can be relied on to increase regional income. One of the economic possibilities referred to is Regional Owned Enterprises or BUMD. BUMD was established as a public organization that organizes productive financial businesses, where all or part of its capital is owned by the region. The profits from its business become part of regional income. Article 331 Paragraph (4) of Law number 23 of 2014 concerning Regional Government, confirms that the establishment of BUMD aims to: (1) provide benefits for the development of the Regional economy in general; (2) providing public benefits in the form of providing quality goods and/or services to fulfill the livelihood of the community according to the conditions, characteristics, and potential of the region concerned based on good corporate governance; and (3) earn profit and/or profit. Thus, it is quite clear about the strategic function of BUMD for regional economic development. Based on the study of the objectives of establishing BUMD as mentioned above, BUMD is expected to be a profit center for local governments and a driving force for Regional strategic potential to be more productive and advanced. Thus, BUMD has a dual motive, namely as a business center and public services. To support these two roles, it is necessary to create more professional and efficient management of BUMD in the vehicle for economic democracy.

Considering that BUMD is a business entity similar to BUMN, regulations regarding BUMD need to refer to the principles that exist in BUMN as regulated in Law Number 19 of 2003. The essential regulatory principles are applying Good Corporate Governance in the management BUMD running in BUMN. Besides, the division of the two forms of BUMD is following the emphasis on the functions carried by BUMD as public service-oriented and profit-oriented, namely in the form 
of a Regional Company (Perusda), which is analogous to a Public Company (Perum) in BUMN and Regional Company (Perseroda) as Persero in the BUMN environment.

According to the author, for more optimal RDF waste management, a regional company should be managed because, according to the author, being driven by a regional company will be professional and flexible towards regulations and freer to develop and innovate. Furthermore, the financial feasibility analysis results show that BUMD regarding waste management in Cilacap Regency is feasible to be established.

\section{CONCLUSION}

The Cilacap Regency Government is a bureaucratic organization with the duty and responsibility to address problems in the public sector, such as the waste problem because it involves many people. The Cilacap Regency Government has chosen to make a public policy in handling waste problems by making a waste management policy with Refused Fuel (RDF) technology to save budget compared to creating a new TPA.

The implementation of the RDF waste management policy in the Cilacap Regency eventually established cooperation between local governments and business entities to jointly manage RDF so that the choice made by Cilacap Regency was operational cooperation with PT. Solusi Bangun Indonesia contributes to each other according to the agreement. There is a huge benefit received by the Cilacap Regency Government, namely an indirect benefit, namely that the waste will be processed quickly so that it reduces the accumulation of waste in TPS, does not need to spend a lot of money for operations to build a new TPA with an open dumping system for the next 15 years or so.

\section{REFERENCES}

1. Azwar, A. (1990). Pengantar Ilmu Kesehatan Lingkungan . Jakarta: Mutiara Sumber Widya.

2. Courtemanche, B., \& Levendis, Y. A. (1998). A Laboratory Study On The NO, $\mathrm{NO} 2, \mathrm{SO} 2, \mathrm{CO}$, and CO2 Emissions from The Combustion of Pulverized Coal, Municipal Waste Plastics, And Tires. Fuel, 77(3), 183-196.

3. Creswell, J. W. (2010). Research Design Pendekatan Kualitatif, Kuantitatif, Dan Mixed. Yogyakarta: Pustaka Pelajar.

4. Damanhuri, E. (2006, April). Teknologi dan Pengelolaan Sampah Kota di Indonesia. In Workshop Nasional Biokonversi Limbah (pp. 11-12).

5. Damanhuri. (2010). Diktat Kuliah: Pengelolaan Sampah. Bandung: ITB.

6. Demirbas, A. (2011). Waste Management, Waste Resource Facilities, and Waste Conversion Processes. Energy Conversion and Management, 52(2), 1280-1287.

7. Dong, T. T., \& Lee, B. K. (2009). Analysis of Potential RDF Resources from Solid Waste and Their Energy Values in The Largest Industrial City Of Korea. Waste Management, 29(5), 1725-1731.

8. Final Report on Waste Specifications Study in Cilacap Regency, 2016. 
9. Genon, G., \& Brizio, E. (2008). Perspectives and Limits For Cement Kilns As A Destination For RDF. Waste Management, 28(11), 2375-2385.

10. Gray, J. M. (1997). Environment, Policy, and Municipal Waste Management in The UK. Transactions of the Institute of British Geographers, 69-90.

11. Himawanto, D. A., Saptoadi, H., Rohmat, T. A., \& Indarto, I. (2010). Pengolahan Sampah Kota Terseleksi Menjadi Refused Derived Fuel Sebagai Bahan Bakar Padat Alternatif. Jurnal Teknik Industri, 11(2), 127-133.

12. Kara, M. (2012). Environmental and Economic Advantages Associated with The Use of RDF in Cement Kilns. Resources, Conservation and Recycling, 68, 21-28.

13. Marshall, R. E., \& Farahbakhsh, K. (2013). Systems Approach Integrated, Solid Waste Management in Developing Countries. Waste Management, 33(4), 988-1003.

14. Misra, V., \& Pandey, S. D. (2005). Hazardous Waste, Impact on Health and Environment for Development of Better Waste Management Strategies in Future In India. Environment International, 31(3), 417-431.

15. Moleong, L. J. (2012). Metodologi Penelitian Kualitatif (Cet. Ke-30.). Bandung: Remaja Rosdakarya.

16. Mulyadi, A., Husein, S., \& Saam, Z. (2010). Perilaku Masyarakat dan Peranserta Pemerintah Daerah dalam Pengelolaan Sampah di Kota Tembilahan. Jurnal Ilmu Lingkungan, 3(02), 147-162.

17. Nahruddin, Z. (2016). Kemitraan Publik-Privat Dalam Pengelolaan Sampah di TPA Tamangapa Kota Makassar. Government: Jurnal Ilmu Pemerintahan, 9(1), 1120.

18. Sahil, J., Al Muhdar, M. H. I., Rohman, F., \& Syamsuri, I. (2016). Sistem Pengelolaan Dan Upaya Penanggulangan Sampah di Kelurahan Dufa-Dufa Kota Ternate. BIOeduKASI, 4(2).

19. Sejati, K. (2009). Pengolahan Sampah Terpadu. Jakarta: Kanisius.

20. Sugiyono, D. (2010). Metode Penelitian Kuantitatif dan RED. Bandung: Alfabeta.

21. Sulistiyorini, N. R., Darwis, R. S., \& Gutama, A. S. (2015). Partisipasi Masyarakat dalam Pengelolaan Sampah di Lingkungan Margaluyu Kelurahan Cicurug. SHARE: Social Work Journal, 5(1).

22. Suyoto, B. (2008). Rumah Tangga Peduli Lingkungan. Jakarta: Prima Media.

23. Yadav, V., Bhurjee, A. K., Karmakar, S., \& Dikshit, A. K. (2017). A Facility Location Model for Municipal Solid Waste Management System Under Uncertain Environment. Science of the Total Environment, 603, 760-771.

24. Yogiesti, V., Hariyani, S., \& Sutikno, F. R. (2012). Pengelolaan Sampah Terpadu Berbasis Masyarakat Kota Kediri. Jurnal Tata Kota dan Daerah, 2(2), 95-102. 